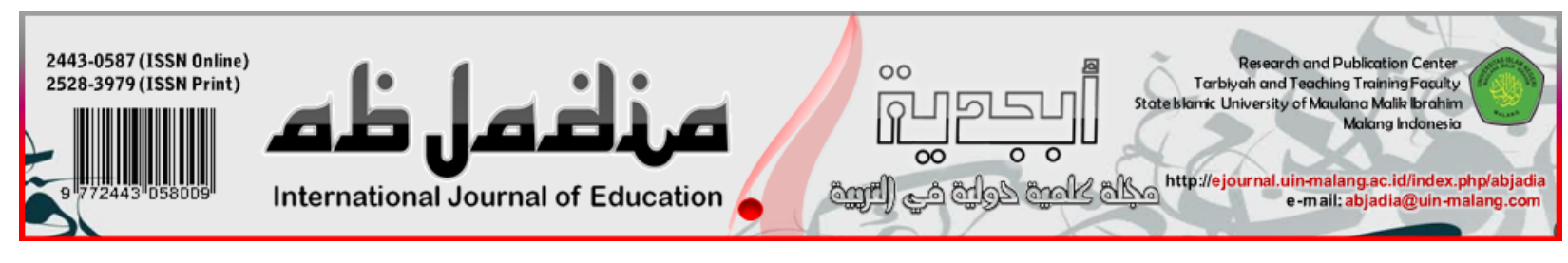

\title{
USER EXPERIENCE (UX) OF MULTIMEDIA; PROGRAM OF AUTO PLAY MEDIA STUDIO FOR TEACHER PROFESSIONAL EDUCATION (PPG)
}

\author{
Mohammad Salehudin ${ }^{*}$, Etty Nurbayani ${ }^{2}$, Rostanti Toba ${ }^{3}$ \\ 1,2,3 IAIN Samarinda; Fakultas Tarbiyah dan Ilmu Keguruan, \\ Jalan HM. Rifadin Loa Janan Ilir Samarinda, Indonesia
}

\begin{abstract}
Article History:
Received : 29-01-2020

Revised : 30-07-2020

Accepted : 27-12-2020

Published : 31-12-2020
\end{abstract}

\section{Keywords:}

User Experience; Multimedia; Teacher Professional

Education (PPG)

*Correspondence Address:

salehudin@iain-samarinda.ac.id

\begin{abstract}
A factor that can influence the success of learning process is the use of learning media. Therefore, this research aims to evaluate the user experience of multimedia using the program of Auto play media studio for Teacher Professional Education (PPG). The research problem is how the teachers use multimedia in learning and how the teachers develop the multimedia by themselves using the computer technology program of media studio auto play. The research method is the user experience (UX) using the instrument from User Experience Questionnaire (UEQ) of Indonesian version, because there are several language versions of the questionnaire built and validated (for example, English, Spanish, Portuguese, etc.) These versions are available for free and online at www.ueq-online.org. The research result from the test of UEQ is that there are five scales which are categorized as excellent; they are Attractiveness, Efficiency, Dependability, Stimulation and Novelty, whereas the scale of Perspicuity is categorized of Above Average according to the interval benchmark of UEQ. All scores are above $<0,08$ shows that the evaluation of UX is positive. It can be concluded that the multimedia learning using the program of is very good - satisfying to use for the Teacher Professional Education for Islamic Education subject (PAI).
\end{abstract}

\section{(C) Introduction}

There are many kinds of multimedia that can be applied in learning. By using learning material of multimedia, the students can be motivated to learn, the motivation role using multimedia overall can improve the students learning (Richard E Mayer, 2014) because the students can listen to the audio, watch the video or see the text, animation and chart simultaneously. All this time, in learning the teacher only used visual media, doing presentation using the simple program which has advantages and limitations in the class. The learning media like that made the students bored, due to lack of variation, such as the use of video, animation, chart, etc. Moreover, there was also no interactive learning between teacher and students. Interactive multimedia is convergent from various media such as video, audio, photo, graphic, animation, and text which are packaged in an integrative and interactive manner (Koesnandar, 2006), finally the multimedia can improve the understanding of the lesson concept (Gunawan, Ahmad Harjono, 2015). 
In the practice of multimedia development requires the expertise in the computer field to support the process of composing multimedia. The problem is that not all teachers have expertise in the computer field. Islamic Education teacher accustomed to use the simple media, just visual media without any interesting interactions. Then through the Teacher Professional Education, all teachers in education is introduced how to plan, design, and make (develop) the interactive multimedia which is not only help the students easier to understand the subject of Islamic Education, but also to improve the quality of teaching from the aspects of cognitive and affective (Roxana Moreno \& Mayer, 2007) even in general to overcome the problem of learning motivation faced by the students especially middle school students in Indonesia for the subject of Islamic Education.

The teachers of Teacher Professional Education being the professional teachers, making and designing the teaching material for the subject of Islamic Education by themselves using Auto play media studio consists of text, picture and videos of dialogue and monologue which are designed creatively. The program used to prepare the teaching material is media studio auto play, it is one of the program which allows the teacher to make the teaching material, learning material, exercise and quiz by the interactive multimedia in the learning at the class.

\section{Theoretical Support}

Teacher Professional Education as an effort towards the teacher professionalism which not only covers the professionalism in educating, guiding, teaching, and evaluating, but also must develop competency in a sustainable manner. Program of Teacher Professional Education which is sought by the government will produce professional teachers who have competences (Alfarisa, 2015), the position of the teacher is increasingly shaded by legal sources and the teachers become mor knowledgeable and professional (Disas, 2012), thus it is expected that the teachers who join the Teacher Professional Education will be more professional, mastering the interactive media (Hasana, S. N., \& Maharany, 2017) especially for learning in the industrial era 4.0 (Mz \& Rahmawati, 2019).

In developing multimedia, the teachers are expected to pay attention to several factors, they are, design creatively according to the students' needs (Rao, 2015), pay attention to the aspects of cognitive and affective (Park, Flowerday, \& Brünken, 2015) and (Park, Plass, \& Brünken, 2014), pay attention to the emotional factor (Heidig, Müller, \& Reichelt, 2015), know the characteristics of multimedia (Sun \& Cheng, 2007), besides some factors above, in the teaching and learning the teacher can combine multimedia with online (Kim, 2018). So in the end the teacher should be the multimedia developer according to the subject matter and the characteristics also the needs of the students in the class and able to spur the improvement of the students motivation in learning. See the picture of learning using media by Moreno at picture 1 . 


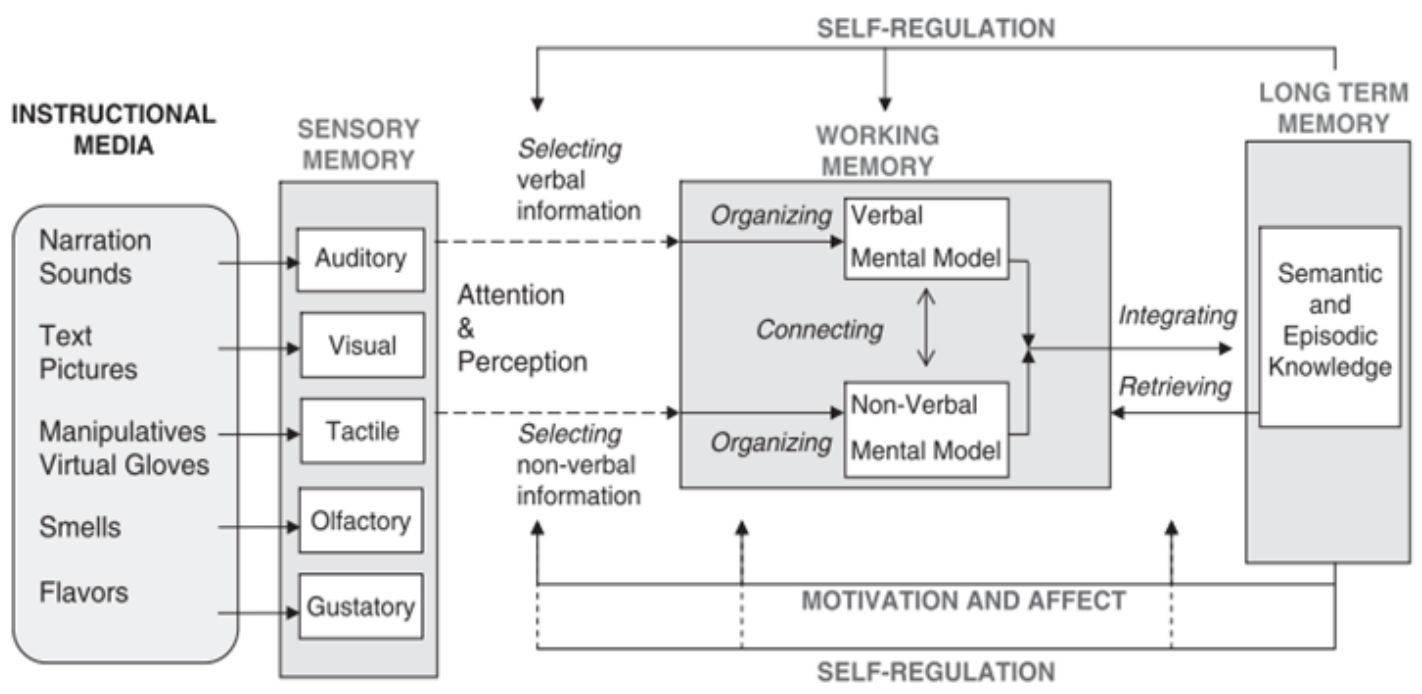

Figure 1. Cognitive-affective theory of learning with media. (R Moreno, 2006), (Roxana Moreno \& Mayer, 2007).

Considering the importance of utilizing multimedia in learning to achieve the learning outcomes, as well as the fulfillment of cognitive and affective aspects in learning, then the design and use of media are the primary concerns of the teachers (see picture flow 1). To strengthen the theory of Moreno (2006), the research towards multimedia done (Hung et al., 2015), multimedia with internet in the learning of English (Thamarana, 2015), multimedia based on computer (R. E. Mayer, 2017) learning theories with media (Ayres, 2015), with some of those researches emphasize that multimedia is very effective in learning if the teachers use it in the class meetings. It can be applied by the teachers in the subject of Islamic Education because it has been used in another subjects and the learning outcomes are very good (for example, English, Math, Physics, etc.).

The teacher is as the user who can design and make his own multimedia (developer). The technology user becomes the determining factor on each activity of the developer, the user experience (UX) is perception and response of someone which produced from the product usage, the professionals design of UX have given a definition (Effie Lai-chong Law, Schaik, \& Roto, 2014), can simply be interpreted how you feel about every interaction that you are facing with what is in front of you when you use it. The user experience is also used in the interactive product (Pucillo, Cascini, Milano, Giuseppe, \& Masa, 2014), User Experience (UX) is dynamic, depends on the context, and subject (Effie L-c Law, Leicester, \& Hassenzahl, 2009). To get the good User Experience, then a product should have compatibility between the product features with the user's need.

Next for the evaluation work of UX discussed the whole user experience (Pucillo et al., 2014), measurement of UX gives response for the design performers (Effie Lai-chong Law et al., 2014), to measure the design and display (Liu, Dey, Ulupinar, Luby, \& Mao, 2015), has been used on the interactive multimedia (Sutcliffe, Hart, Sutcliffe, \& Hart, 2016). While to know the test result of UX, and then there are many quantitative 
instruments can be done, including the instrument using User Experience Questionnaire (UEQ) which is available online. UEQ has also been used in assessing the interactive media (Schrepp, Hinderks, \& Thomaschewski, 2014) has benchmark and efficient in measuring the user experience of a product quantitatively (Schrepp, Hinderks, \& Thomaschewski, 2017). As the test tool of UX, then UEQ has benchmark with six scales, they are; Attractiveness, Efficiency, Perspicuity, Dependability, Simulation and Novelty. See Figure 2:

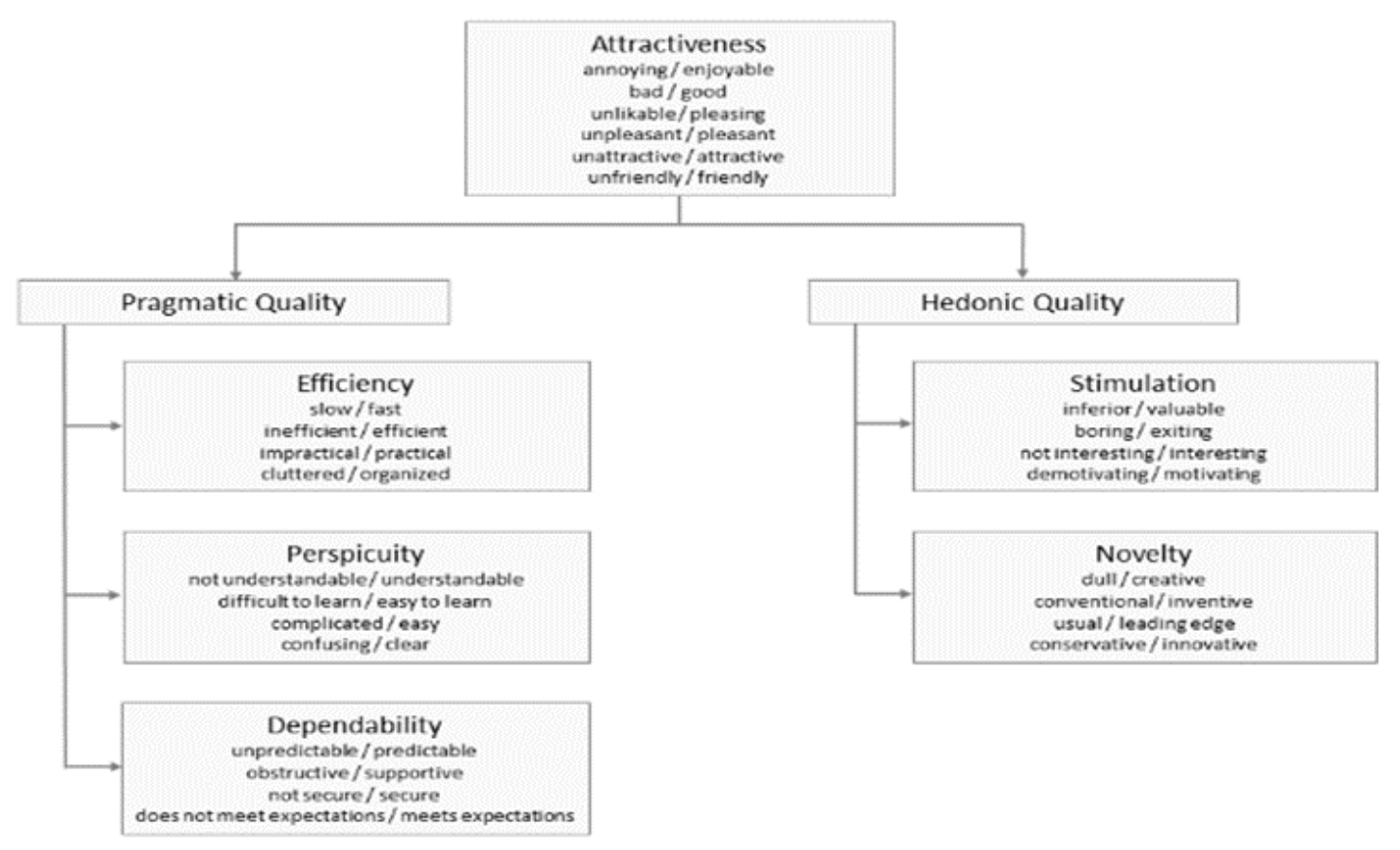

Figure 2. Assumed scale structure of the UEQ. (Schrepp et al., 2014), (Schrepp, 2015).

With the six scales owned by UEQ, the test result and analysis can find out the user experience (UX) on the technology usage including the multimedia device based on the computer program, in this case the test of UX the usage of the Auto play media studio program for multimedia developed by the teachers of Teacher Professional Education. The result of UEQ takes into consideration of the technology user even from the design and content used to achieve the maximum learning outcomes

From the explanation about the important of multimedia in the learning above, if the teachers are able to plan, design and make multimedia based on technology by them (developer), then the multimedia will be appropriate to the students emotional, will have the motivation strength in learning and can achieve good learning outcomes. Therefore, the research towards the user experience (UX) being important to be done, because UX being the direction determinant of the technology usage as the multimedia tool which can be used for all subjects including Islamic Education. So the research aim is to evaluate the user experience of technology based on multimedia computer of Auto play media studio program on Islamic Education subject at the Teacher Professional Education. 


\section{[Q] Method}

The research participants of User Experience (UX) of multimedia of Auto play media studio computer program in the workshop of Teacher Professional Education of IAIN Samarinda in the year of 2019 are 22 and the participants who give the answer are 16.

The researcher collected the quantitative data using User Experience Questionnaire (UEQ) online and open question related to the user experience of multimedia. The research used Indonesian version, because there are several language versions from the questionnaire built and evaluated (for example, English, Spanish, Portuguese, etc.). These versions are available for free at www.ueq-online.org. There are 26 items of questionnaire. The participants give the answers in 10-15 minutes.

The reliability of UEQ scale is usually high, that is, the coefficient of CronbachAlpha is usually more than 0,7 with the benchmark of UEQ on the six elements or scales, translated into Indonesian: Daya Tarik, Kejelasan, Efisiensi, Ketepatan, Stimulasi, dan Kebaruan.

\section{Result}

The researcher collected the quantitative data using User Experience Questionnaire (UEQ) online and open question, the respondents' answers for each question, performed the calculation of mean, variance and standard deviation. Each question is given a color code as the group; they are attractiveness, perspicuity, efficiency, dependability, stimulation, and novelty.

Table 1: The quality of respondents' answer result

\begin{tabular}{cccccccl}
\hline Item & Mean & Variance & $\begin{array}{c}\text { Std. } \\
\text { Dev. }\end{array}$ & No. & Left & Right & Scale \\
\hline 1 & 1,9 & 2,1 & 1,5 & 16 & Annoying & enjoyable & Attractiveness \\
\hline 2 & 1,6 & 1,3 & 1,1 & 16 & not understandable & understandable & Perspicuity \\
\hline 3 & 1,8 & 3,3 & 1,8 & 16 & Creative & dull & Novelty \\
\hline 4 & 1,1 & 2,6 & 1,6 & 16 & easy to learn & difficult to learn & Perspicuity \\
\hline 5 & 2,6 & 0,5 & 0,7 & 16 & Valuable & inferior & Stimulation \\
\hline 6 & 1,9 & 1,9 & 1,4 & 16 & Boring & exciting & Stimulation \\
\hline 7 & 2,3 & 0,8 & 0,9 & 16 & not interesting & interesting & Stimulation \\
\hline 8 & 1,4 & 2,5 & 1,6 & 16 & Unpredictable & predictable & Dependability \\
\hline 9 & 1,6 & 1,9 & 1,4 & 16 & Fast & slow & Efficiency \\
\hline 10 & 2,3 & 1,4 & 1,2 & 16 & Inventive & conventional & Novelty \\
\hline 11 & 2,3 & 1,0 & 1,0 & 16 & Obstructive & supportive & Dependability \\
\hline 12 & 2,6 & 0,5 & 0,7 & 16 & Good & bad & Attractiveness \\
\hline 13 & 0,7 & 3,6 & 1,9 & 16 & Complicated & easy & Perspicuity \\
\hline 14 & 2,0 & 1,2 & 1,1 & 16 & Unlikable & pleasing & Attractiveness \\
\hline 15 & 1,3 & 2,3 & 1,5 & 16 & Usual & leading edge & Novelty \\
\hline
\end{tabular}




\begin{tabular}{cccccccl}
\hline 16 & 1,9 & 1,1 & 1,1 & 16 & Unpleasant & pleasant & Attractiveness \\
\hline 17 & 2,0 & 2,9 & 1,7 & 16 & Secure & not secure & Dependability \\
\hline 18 & 2,6 & 0,7 & 0,8 & 16 & Motivating & demotivating & Stimulation \\
\hline 19 & 2,3 & 1,0 & 1,0 & 16 & meets expectations & $\begin{array}{c}\text { does not meet } \\
\text { expectations }\end{array}$ & Dependability \\
\hline 20 & 2,2 & 1,1 & 1,0 & 16 & Inefficient & efficient & Efficiency \\
\hline 21 & 1,3 & 2,8 & 1,7 & 16 & Clear & confusing & Perspicuity \\
\hline 22 & 2,0 & 0,9 & 1,0 & 16 & Impractical & practical & Efficiency \\
\hline 23 & 2,3 & 0,6 & 0,8 & 16 & Organized & cluttered & Efficiency \\
\hline 24 & 1,3 & 3,2 & 1,8 & 16 & Attractive & unattractive & Attractiveness \\
\hline 25 & 1,9 & 2,9 & 1,7 & 16 & Friendly & unfriendly & Attractiveness \\
\hline 26 & 2,4 & 1,1 & 1,0 & 16 & Conservative & innovative & Novelty \\
\hline
\end{tabular}

Seen from the table, each item of the answer has a mean, variance and standard deviation which are then known the scale category of the answer result for each item. It can be concluded by the mean and variance as follows:

Table 2. Mean and variance of UEQ

\begin{tabular}{lcl}
\hline \multicolumn{1}{c}{ UEQ Scales (Mean and Variance) } & \\
\hline Attractiveness & 1,927 & 1,06 \\
\hline Perspicuity & 1,172 & 1,81 \\
\hline Efficiency & 2,016 & 0,79 \\
\hline Dependability & 1,984 & 1,28 \\
\hline Stimulation & 2,359 & 0,58 \\
\hline Novelty & 1,906 & 0,61 \\
\hline
\end{tabular}

Next, to calculate the score range of each scale is by inserting the benchmark on UEQ. A benchmark that already existed for UEQ determined the practical score range for the factors of UEQ from the evaluation result of UX of interactive multimedia of Auto play media studio on the Teacher Professional Education, thus it can be estimated better.

Table 3. Results of mean and benchmark of UEQ

\begin{tabular}{ccc} 
Scale & Mean & Comparisson to benchmark \\
\hline Attractiveness & 1,93 & Excellent \\
\hline Perspicuity & 1,17 & Above Average \\
\hline Efficiency & 2,02 & Excellent \\
\hline Dependability & 1,98 & Excellent \\
\hline Stimulation & 2,36 & Excellent \\
\hline Novelty & 1,91 & Excellent \\
\hline
\end{tabular}

Based on the diagram of benchmark result of UEQ, there are five scales that categorized as excellent; they are the scales of Attractiveness, Efficiency, Dependability, Stimulation and Novelty. While the scale of Perspicuity is categorized as Above Average 
according to the benchmark interval of UEQ which has been set. To find out the calculation benchmark on UEQ, can be seen on the following figure:

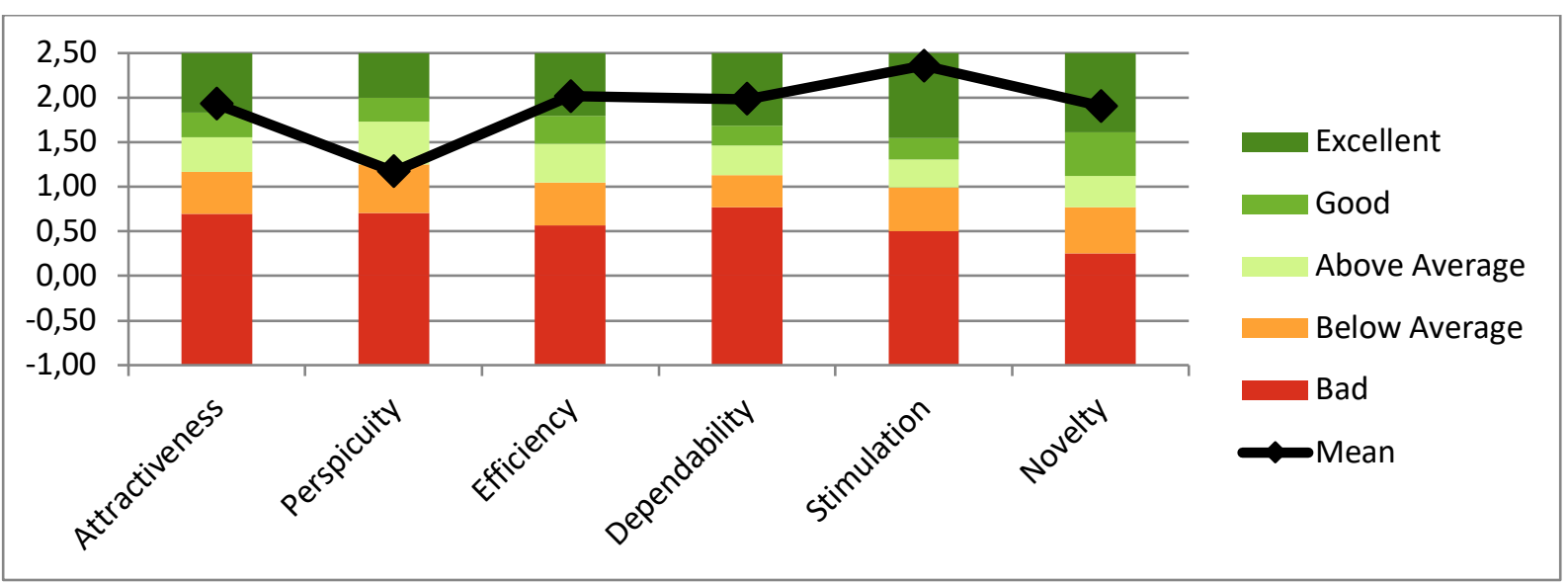

Figure 3. Benchmark Chart of UEQ

It shows the chart of the mean of questions according to the group. The impression mean between -0.8 and 0.8 is the normal evaluation score, score $>0.8$ is positive evaluation and the scores $<-0.8$ are negative evaluation. Then it can be concluded that the multimedia program of Auto play media studio, likely to have positive impression (the score is in the direction of 1 and above) decreasing successively in the groups of efficiency, attractiveness, dependability, perspicuity, stimulation and novelty.

Table 4. Scores of each scale and benchmark of UEQ

\begin{tabular}{lccccccc}
\hline Scale & $\begin{array}{c}\text { Lower } \\
\text { Border }\end{array}$ & Bad & $\begin{array}{c}\text { Below } \\
\text { Average }\end{array}$ & $\begin{array}{c}\text { Above } \\
\text { Average }\end{array}$ & Good & Excellent & Mean \\
\hline Attractiveness & $-1,00$ & 0,7 & 0,47 & 0,39 & 0,27 & 0,67 & 1,93 \\
\hline Perspicuity & $-1,00$ & 0,71 & 0,54 & 0,48 & 0,27 & 0,5 & 1,17 \\
\hline Efficiency & $-1,00$ & 0,57 & 0,48 & 0,43 & 0,32 & 0,7 & 2,02 \\
\hline Dependability & $-1,00$ & 0,77 & 0,36 & 0,33 & 0,23 & 0,81 & 1,98 \\
\hline Stimulation & $-1,00$ & 0,5 & 0,49 & 0,32 & 0,24 & 0,95 & 2,36 \\
\hline Novelty & $-1,00$ & 0,25 & 0,52 & 0,35 & 0,49 & 0,89 & 1,91 \\
\hline
\end{tabular}

On the table 4 explained that the mean position and the score condition on each scale on the benchmark which are determined by UEQ, means that the scores show the result found on each scale.

\section{¡ị Discussion}

UEQ determined six scales; Attractiveness, Efficiency, Perspicuity, Dependability, Simulation and Novelty. See the research result above, it is found that the five scales on the benchmark position of Excellent are Attractiveness (1,93), Efficiency $(2,02)$, Dependability $(1,98)$, Simulation $(2,36)$ and Novelty $(1,91)$, while the scores on the benchmark of Above Average is only one; that is Perspicuity $(1,17)$. From the scores above $<0.8$ show the positive evaluation. 
If the mean above $<0.8$ on all scales and benchmark of UEQ shows the positive evaluation, then using multimedia based on computer technology of auto play media studio program can be applied on the subject of Islamic Education for middle schools. Because there are multimedia strengths such as the strengths of theory and multimedia application in the learning which have a big influence in the learning outcomes achievement (Clark, 1992), multimedia gives influence on the learning outcomes of cognitive and affective (Roxana Moreno \& Mayer, 2007) and multimedia has been used on some subjects, for example Math (Chiu \& Churchill, 2015), and English (Ampa, 2015). So the use of multimedia in the learning of Islamic Education can be applied well.

The use of multimedia which is related to the professional teacher has become a demand that should be applied as strengthening the competence. Through the Teacher Professional Education (PPG) is expected that professional teachers will be materialized with the good learning competence, because a professional teacher concerned to the demand of the times (Alfarisa, 2015), already know of its existence in the industrial era 4.0 (Mz \& Rahmawati, 2019). Therefore the professional teachers of Islamic Education should concern to the competence in the utilization of learning media maximally, have high creativity ability in developing the multimedia they made.

Thus the positive evaluation result towards the user experience (UX) of multimedia of Auto play media studio program will give benefits in Islamic Education learning in the class. As an important note that it is need to be concerned for the aspect and factors of the multimedia developer. It can be from the factors of emotional, characteristic and cognitive -affective of the learning outcomes also the computer mastery in particular.

\section{眘 Conclusion}

The mean scores found above $<0.8$, show the positive evaluation towards the use of multimedia technology. The teacher can use it very well - satisfying, the professional teacher can design, not only making the learning material, but also composing media text, video and interactive sound added by the quiz facility with the creative design of developer on the multimedia of Auto play media studio program for the subject of Islamic Education and the professional teacher also demanded to be able to utilize the multimedia well in the class.

\section{Acknowledgment}

The IAIN Samarinda teacher professional education team and the dean of FTIK IAIN Samarinda. 


\section{Bibliography}

Alfarisa, atna R. P. \& F. (2015). Pendidikan Profesi Guru (Ppg): Strategi Pengembangan Profesionalitas Guru Dan Peningkatan Mutu Pendidikan Indonesia. Prosiding Seminar Nasional, 671-683.

Ampa, A. T. (2015). The Implementation of Interactive Multimedia Learning Materials in Teaching Listening Skills. English Language Teaching, 8(12), 56-62. https://doi.org/10.5539/elt.v8n12p56

Ayres, P. (2015). State-of-the-Art Research into Multimedia Learning : A Commentary on Mayer' s Handbook of Multimedia Learning. Applied Cognitive Psychology, 29(4), 631-636. https://doi.org/10.1002/acp.3142

Chiu, T. K. F., \& Churchill, D. (2015). Design of learning objects for concept learning: effects of multimedia learning principles and an instructional approach. Interactive Learning Environments, 24(6), 37-41. https://doi.org/10.1080/10494820.2015.1006237

Clark, R. E. (1992). Research and Theory on Multi-Media Learning Effects. Interactive Multimedia Learning Environments, 19-30. https://doi.org/10.1007/978-3-64277705-9

Disas, E. P. (2012). Analisis kebijakan pendidikan mengenai pengembangan dan peningkatan profesi guru. Jurnal Penelitian Pendidikan, (14).

Gunawan, Ahmad Harjono, S. (2015). Multimedia Interaktif Dalam Pembelajaran Konsep Listrik Bagi Calon Guru. Jurnal Pendidikan Fisika Dan Teknologi, I(1), 9-14.

Hasana, S. N., \& Maharany, E. R. (2017). Pengembangan multimedia menggunakan Visual Basic for Application (VBA) untuk meningkatkan profesionalisme guru matematika. JPM Jurnal Pendidikan Matematika, 3(2), 30-40.

Heidig, S., Müller, J., \& Reichelt, M. (2015). Emotional design in multimedia learning: Differentiation on relevant design features and their effects on emotions and learning. Computers in Human Behavior, 44, 81-95. https://doi.org/10.1016/j.chb.2014.11.009

Hung, H., Bernd, J., Gordo, B., Choi, J., Morgan, B., Egelman, S., ... Friedland, G. (2015). Teaching Privacy : Multimedia Making a Difference “ W. 12-19.

Kim, D. (2018). Adoption of multimedia technology for learning and gender difference Adoption of multimedia technology for learning and gender difference. Computers in Human Behavior. https:// doi.org/10.1016/j.chb.2018.11.029

Koesnandar, A. (2006). Pengembangan Software Pembelajaran Multimedia Interaktif. Jurnal Teknodik, 18(X), 75-88.

Law, Effie L-c, Leicester, L. E., \& Hassenzahl, M. (2009). Understanding, Scoping and 
Defining User experience: A Survey Approach. Proceedings of the 27th International Conference on Human Factors in Computing Systems - CHI, 719-728.

Law, Effie Lai-chong, Schaik, P. Van, \& Roto, V. (2014). Attitudes towards User Experience ( UX ) Measurement. Journal of Human-Computer Studies, 72(6), 526541.

Liu, Y., Dey, S., Ulupinar, F., Luby, M., \& Mao, Y. (2015). Deriving and Validating User Experience Model for DASH Video Streaming. IEEE Transactions On Broadcasting, 61(4), 651-665.

Mayer, R. E. (2017). Using multimedia for e-learning. Journal of Computer Assisted Learning, 33(5), 403-423. https://doi.org/10.1111/jcal.12197

Mayer, Richard E. (2014). Incorporating motivation into multimedia learning. Learning and Instruction, 29, 171-173.

Moreno, R. (2006). Does the modality principle hold for different media? A test of the method-affects-learning hypothesis. Journal of Computer Assisted Learning, 22(3), 149-158. https:/ / doi.org/10.1111/j.1365-2729.2006.00170.x

Moreno, Roxana, \& Mayer, R. (2007). Interactive Multimodal Learning Environments. Educ Psychol Rev, 19, 309-326. https:/ / doi.org/10.1007/s10648-007-9047-2

Mz, S., \& Rahmawati, F. (2019). Peranan Guru Dalam Penggunaan Multimedia Interaktif Di Era Revolusi Industri 4.0. Prosiding Seminar Nasional Pendidikan Program Pascasarjana Universitas Pgri Palembang.

Park, B., Flowerday, T., \& Brünken, R. (2015). Computers in Human Behavior Cognitive and affective effects of seductive details in multimedia learning. Computers in Human Behavior, 44, 267-278. https:/ / doi.org/10.1016/j.chb.2014.10.061

Park, B., Plass, J. L., \& Brünken, R. (2014). Cognitive and affective processes in multimedia $\begin{array}{llll}\text { learning. Learning } & \text { Instruction, 29, }\end{array}$ https://doi.org/10.1016/j.learninstruc.2013.05.005

Pucillo, F., Cascini, G., Milano, P., Giuseppe, V., \& Masa, L. (2014). A framework for user experience, needs and affordances. Design Studies, 35(2), 160-179. https:/ / doi.org/10.1016/j.destud.2013.10.001

Rao, K. (2015). Universal Design for Learning and Multimedia Technology: Supporting Culturally and Linguistically Diverse Students. Journal of Educational Multimedia and Hypermedia, 24(2), 121-137.

Schrepp, M. (2015). User Experience Questionnaire Handbook. (September). https://doi.org/10.13140/RG.2.1.2815.0245

Schrepp, M., Hinderks, A., \& Thomaschewski, J. (2014). Applying the User Experience Questionnaire ( UEQ ) in different evaluation scenarios Construction of the User 
Experience Questionnaire ( UEQ ). International Conference of Design, User Experience, and Usability, 383-392. Springer, Cham.

Schrepp, M., Hinderks, A., \& Thomaschewski, J. (2017). Construction of a Benchmark for the User Experience Questionnaire ( UEQ ). International Journal of Interactive Multimedia and Artificial Intelligence (IJIMAI), 4(4), 40-44. https://doi.org/10.9781/ijimai.2017.445

Sun, P., \& Cheng, H. K. (2007). The design of instructional multimedia in e-Learning: A Media Richness Theory-based approach. Computers \& Education, 49, 662-676. https://doi.org/10.1016/j.compedu.2005.11.016

Sutcliffe, A., Hart, J., Sutcliffe, A., \& Hart, J. (2016). Analysing the Role of Interactivity in User Experience. International Journal of Human-Computer Interaction, 33(3), 229240. https:/ / doi.org/10.1080/10447318.2016.1239797

Thamarana, S. (2015). Role of Multimedia Resources in Teaching and Learning of English Language. 3rd Annual International Conference by English Language Teachers' Association of India (ELTAI) TIRUPATI CHAPTER, (april). https://doi.org/10.13140/RG.2.1.2043.6723.

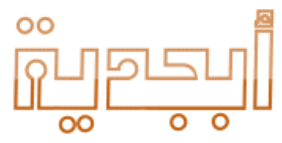

